\title{
DAMPAK PEMBANGUNAN PARIWISATA PANTAI PANJANG TERHADAP KESEJAHTERAAN MASYARAKAT PESISIR DI KOTA BENGKULU
}

\author{
Oleh: \\ Adi Sutojo 1 \\ Hernowo Novi Yanto
}

\begin{abstract}
ABSTRAKSI
Pembangunan industri pariwisata di Kota Bengkulu dilatar belakangi dengan adanya berbagai pemikiran, bahwa secara geografis Kota Bengkulu memiliki daya tarik tersendiri bagi daerah pariwisata, dengan memiliki keragaman potensial alam maupun potensi budayanya. Pendekatan penelitian adalah kualitatif deskriptif, dengan menganalisis dampak pembangunan pariwisata pantai panjang di Kota Bengkulu. Hasil penelitian menjelaskan bahwa secara umum, pembangunan pariwisata Pantai Panjang berdampak positif terhadap sosial budaya masyarakat pesisir Kota Bengkulu yaitu peningkatan pendapatan masyarakat dan tingkat pendidikan masyarakat juga meningkat. Dari segi ekonomi, dampak positif dari pengembangan pariwisata Pantai Panjang terhadap kemajuan ekonomi di daerah ini begitu besar karena partisipasi masyarakat terhadap kegiatan pariwisata cukup Tinggi. Hal tersebut dikarenakan antara lain masyarakat memiliki ketrampilan dalam bidang pariwisata, namun peluang untuk bekerja bersifat tertutup, peluang usaha terbatas, tidak memiliki modal, serta ketidaktahuan masyarakat akan adanya peluang usaha bidang pariwisata. Namun, pariwisata juga dapat berdampak negatif, seperti terjadinya degradasi sosial-budaya masyarakat. Dampak negatif juga bisa terjadi pada perekonomian masyarakat di mana terjadi kesenjangan pendapatan dan kesejahteraan masyarakat antara pelaku pariwisata dengan masyarakat lain yang tidak bersentuhan dengan pariwisata secara langsung, serta ketidak berdayaan masyarakat lokal dalam hal persaingan ekonomi dengan investor dari luar daerah.
\end{abstract}

Kata Kunci : Pembangunan Pariwisata,Kesejahteraan, Bengkulu

\footnotetext{
${ }^{1}$ Dosen Tetap Prodi Ilmu Administrasi Negara Fisip Unihaz Bengkulu

2 Dosen Tetap Prodi Ilmu Administrasi Negara Fisip Unihaz Bengkulu
} 


\section{A. Pendahuluan}

Pariwisata telah menjadi salah satu industri terbesar di dunia, dan merupakan andalan utama dalam menghasilkan devisa diberbagai negara. Pariwisata berkembang karena adanya gerakan manusia di dalam mencari sesuatu yang belum diketahuinya, menjelajahi wilayah yang baru, mencari perubahan suasana, atau untuk mendapat perjalanan baru (Robinson, 1976: Murphy, 1985). Ditinjau berdasarkan dampak positifnya, dengan berkembanganya Menurut Undang-Undang No. 25 Tahun 2000 tentang Program Pembangunan Nasional, maka tujuan pembangunan pariwisata adalah 1) mengembangkan dan memperluas diversifikasi produk dan kualitas pariwisata nasional; 2) berbasis pada pemberdayaan masyarakat, kesenian dan sumber daya (pesona) alam lokal dengan memperhatikan kelestarian seni dan budaya tradisional serta kelestarian lingkungan hidup setempat, dan 3) mengembangkan serta memperluas pasar pariwisata terutama pasar luar negeri (Depbudpar, 2000 dalam Wisnawa, 2009).

Dampak positif yang dapat dirasakan oleh masyarakat pesisir dengan pembangunan kawasan pariwisata bahari yaitu meningkatnya perekonomian masyarakat karena dengan adanya pembangunan pariwisata bahari masyarakat pesisir dapat mengelolah warung makan, pusat oleh-oleh/sovenir, homesatay, menjadi guide, selain itu sarana-prasarana yang memadai yang dibangun oleh pemerintah seperti tempat pelelangan ikan, jalan dan transportasi.

Pariwisata merupakan salah satu industri yang kelangsungan hidupnya sangat ditentukan oleh baik-buruknya lingkungan. Karena itu pengembangan pariwisata haruslah memperhatikan terjaganya mutu lingkungan, sebab dalam industri pariwisata lingkungan itulah yang sebenarnya menjadi nilai jual.

Menurut Wiranatha (2008, dalam Faizun,2009), perkembangan kepariwisataan memberikan dampak positif maupun negatif terhadap daerah dan masyarakat di mana kegiatan pariwisata tersebut dilaksanakan. Secara umum pembangunan kawasan wisata bahari akan memiliki dampak positif atau negatif terhadap lingkungan, sosial dan ekonomi masyarakat

Pengembangkan sektor pariwisata di Kota Bengkulu juga sangat diperlukan program yang terarah dan tepat di dalam meningkatkan jumlah kedatangan wisatawan domestik maupun mancanegara. Hal yang dimaksud perlu didukung pula dengan kegiatan untuk meningkatkan promosi serta perbaikan dari berbagai fasilitas pendukung pariwisata, seperti pelayanan imigrasi, fasilitas transportasi, perbankan, akomodasi, restoran, biro perjalanan dan banyak hal lainnya. Berdasarkan identifikasi permasalahan yang ada, maka sudah seharusnya Dinas Kebudayaan dan Pariwisata Provinsi Bengkulu sebagai leading sector di dalam pengembangan pariwisata daerah ini, untuk melakukan pendataan dan analisis kunjungan wisatawan secara berkala.

Pada dasarnya, pemerintah daerah di Provinsi Bengkulu telah membuat strategi guna pengembangan pariwisatanya, namun optimalisasi di dalam pelaksanaannya belum memberikan dampak yang signifikan terhadap kenyataan yang ada. Hal ini dirasakan oleh peneliti, dikarenakan belum progresifnya pemerintah daerah dalam melibatkan stakeholder pariwisata, diantaranya adalah pihak bisnis maupun masyarakat lokal. Sehingga di dalam penelitian ini, peneliti mencoba mengidentifikasi masalah dan selanjutnya menganalisis dampak pengembangan pariwisata Pantai Panjang terhadap kesejahteraan masyarakat pesisir Kota Bengkulu.

Berdasarkan uraian latar belakang diatas, maka rumusan masalah di dalam penelitian ini, yaitu; "Bagaimana Dampak pengembangan pariwisata Pantai Panjang terhadap Kesejahteraan masyarakat Pesisir Kota Bengkulu?.

Merujuk pada rumusan masalah diatas, maka tujuan yang ingin dicapai di dalam penelitian ini, yaitu untuk menganalisis Dampak pengembangan pariwisata terhadap Kesejahteraan masyarakat Pesisir Kota Bengkulu.

\section{B. Metode Penelitian}

Penelitian ini menggunakan pendekatan deskriptif kualitatif. Teknik pengumpulan data dilakukan dengan metode wawancara, observasi, dan dokumentasi. Lokasi penelitian di Pantai Panjang Kota Bengkulu

Dalam penelitian ini data-data yang diperoleh berdasarkan sumbernya dapat digolongkan menjadi dua bagian yaitu data primer dan data sekunder. Data primer merupakan data yang diperoleh dari informan dengan cara wawancara maupun 
pengamatan secara langsung, sedangkan data sekunder merupakan data yang bersumber dari dokumen-dokumen arsip tertentu yang berhubungan dengan penelitian (Koentjaraningrat, 1991:37).

C. Hasil Penelitian dan Pembahasan

1. Dampak Pembangunan Pariwisata Pantai Panjang Terhadap Kehidupan Sosial Budaya Pesisir di Kota Bengkulu

Secara umum, pariwisata berdampak positif terhadap Sosial Budaya Masyarakat Pesisir Kota Bengkulu yaitu peningkatan pendapatan masyarakat dan tingkat pendidikan masyarakat juga meningkat. Namun, pariwisata juga dapat berdampak negatif, seperti terjadinya degradasi sosialbudaya masyarakat. Dampak negatif juga bisa terjadi pada perekonomian masyarakat di mana terjadi kesenjangan pendapatan dan kesejahteraan masyarakat antara pelaku pariwisata dengan masyarakat lain yang tidak bersentuhan dengan pariwisata secara langsung, serta ketidakberdayaan masyarakat lokal dalam hal persaingan ekonomi dengan investor dari luar daerah.

Sebenarnya perubahan sosial budaya tidak selalu negatif. Yang menjadi persoalan dalam interaksi antara masyarakat lokal dengan para wisatawan adalah ketidak mampuan masyarakat menangkap dengan jelas budaya yang dibawa oleh para wisatawan dan ketidak siapan masyarakat dalam menghadapi perubahan oleh para wisatawan dan ketidaksiapan masyarakat dalam menghadapi perubahan yang terjadi, khususnya yang disebabkan oleh perubahan kondisi ekonomi masyarakat. Kondisi demikian menyebabkan masyarakat lokal tidak jarang melakukan suatu peniruanpeniruan budaya masyarakat pendatang (wisatawan) secara tidak tepat yang didukung oleh kondisi ekonomi yang lebih mencukupi untuk melakukan berbagai peniruan budaya tersebut. Padahal di sisi lain budaya khas masyarakat lokal merupakan bagian yang tidak terpisahkan dari kegiatan pariwiata (Sunarminto, 2002).

Pola pengembangan pariwisata di provinsi Bengkulu membutuhkan partisipasi yang aktif dari masyarakat lokal, karena masyarakat lokal bukan hanya diposisikan sebagai obyek semata, akan tetapi lebih diberdayakan untuk kelangsungan pengembangan pariwisata. Untuk itu, maka sasaran pemberdayaan masyarakat lokal dalam kaitannya pengembangan pariwisata di Provinsi Bengkulu dapat dicapai jika sumber daya masyarakat lokal tersebut sudah siap untuk terlibat dalam proses pengembangan pariwisata, untuk itu dilakukan upaya peningkatan SDM masyarakat lokal yang akan terlibat dalam pengembangan pariwisata. Melihat perlunya keterlibatan masyarakat lokal dalam pengembangan pariwisata untuk peningkatan kunjungan wisatawan, maka isu strategisnya adalah: Meningkatkan pemberdayaan masyarakat lokal dalam pengembangan obyek wisata alam dan budaya.

\section{Dampak Pembangunan Pariwisata Pantai Panjang terhadap Perekonomian Masyarakat Pesisir di Kota Bengkulu}

Dari segi ekonomi, dampak positif dari pengembangan pariwisata Pantai Panjang terhadap penerimaan ekonomi di daerah ini begitu besar karena partisipasi masyarakat terhadap kegiatan pariwisata cukup Tinggi. Hal tersebut dikarenakan antara lain masyarakat memiliki keterampilan dalam bidang pariwisata, namun peluang untuk bekerja bersifat tertutup, peluang usaha terbatas, tidak memiliki modal, serta ketidaktahuan masyarakat akan adanya peluang usaha bidang pariwisata.

Sedangkan untuk mendukung kegiatan pengembangan obyek wisata Pantai Panjang, sarana dan prasarana yang memadai sangat dibutuhkan untuk meningkatkan efektivitas kinerja. Melihat dari kelemahan yang ada, maka hal tersebut perlu dimaksimalkan dengan menangkap peluang berupa adanya komitmen manajemen puncak untuk mengembangkan pariwisata dan budaya, dan bergulirnya paradigma baru pengembangan pariwisata berbasis alam dan budaya

Dengan melihat sarana dan prasarana kerja dalam rangka menunjang kegiatan pariwisata yang belum memadai tersebut, maka perlu ditanggapi oleh pemerintah daerah secara serius dan responsif karena kelengkapan sarana dan prasarana sangat dibutuhkan, dan penggunaan peluang terkait dengan meminimalkan kelemahan yang ada, maka isu strategis yang perlu dikembangkan adalah meningkatkan sarana dan prasarana kerja untuk menunjang kegiatan pariwisata. Dalam mendukung kegiatan pengembangan obyek wisata, 
fasilitas yang memadai sangat dibutuhkan untuk meningkatkan pelayanan kepada wisatawan. Melihat dan kelemahan yang ada berupa fasilitas wisata yang belum memadai, maka hal tersebut perlu diminimalkan dengan menangkap peluang berupa adanya peningkatan partisipasi masyarakat, serta para pelaku usaha pariwisata dalam mennyediakan fasilitas yang dibutuhkan wisatawan.

\section{Kesimpulan dan Saran}

\section{Kesimpulan}

Secara umum, pembangunan pariwisata Pantai Panjang berdampak positif terhadap sosial budaya masyarakat pesisir Kota Bengkulu yaitu peningkatan pendapatan masyarakat dan tingkat pendidikan masyarakat juga meningkat. Namun, pariwisata juga dapat berdampak negatif, seperti terjadinya degradasi sosial-budaya masyarakat. Dampak negatif juga bisa terjadi pada perekonomian masyarakat di mana terjadi kesenjangan pendapatan dan kesejahteraan masyarakat antara pelaku pariwisata dengan masyarakat lain yang tidak bersentuhan dengan pariwisata secara langsung, serta ketidak berdayaan masyarakat lokal dalam hal persaingan ekonomi dengan investor dari luar daerah.

\section{Saran}

Berdasarkan kesimpulan di atas, maka disarankan agar pemerintah daerah setempat, khususnya Dinas Pariwisata Kota Bengkulu untuk mengoptimalkan pendidikan dalam pengembangan pariwisata maka pemerintah harus membangun pendidikan kepariwisataan, pelatihan kepariwisataan, dan meningkatkan sarana dan prasarana serta fasilitas rekreasi dengan lebih baik lagi di obyek wisata pantai Pantai Panjang, maka masyarakat diharapkan dapat meningkatkan kegiatan usahanya dengan menyediakan berbagai fasilitas rekreasi dan dagangannya yang pada dan akhirnya akan meningkatkan pendapatan masyarakat sehingga masyarakat dapat merasakan dampak pembangunan obyek wisata pantai Panjang.

\section{DAFTAR PUSTAKA}

\section{Sumber dari Buku :}

Agus Prayogi, Putu. 2014. Dampak Perkembangan Pariwisata di Objek Wisata Penglipuran. [internet]. (diunduh pada tanggal 23 November 2014. Dapat diunduh dari: www.triatmajaya.triatma- mapindo.ac.id/.../journals/.

Bengen, D.G. 2001. Ekosistem dan Sumberdaya Alam Pesisir dan Laut (Sinopsis), Pusat Kajian Sumberdaya Pesisir dan Lautan (PKSPL). Bogor: Institut Pertanian Bogor.

Dewi, K., 2013, "Dampak Perkembangan Wisata Bahari Terhadap Ekonomi Masyarakat Pesisir Kabupaten Batu Bara”. Jurusan Pendidikan Sejarah, Fakultas Ilmu Sosial, Universitas Medan.

Djojohandikusumo, Soemitro. 1985. Ekonomi Kerakyatan dan Pengusaha Kecil Indonesia Tantangan Masa Depan. FE UI. Jakarta.Dirjen Pariwisata. 1996. Perencanaan Pengembangan Destinasi Pariwisata. UIPress, Jakarta

Dahuri, R., J. Rais, S. P. Ginting, J. Sitepu. 2005. Pengelolaan Sumberdaya Wilayah Pesisir dan Lautan Secara Terpadu. Jakarta: Pradnya Paramita.

Dewantama, M.I., N.K. Mardini, I.B.W. Adnyana. 2007. Studi Evektivitas Pengelolaan Kolaboratif Kawasan Perairan Taman Nasional Bali BaratTerhadapa Tutupan Karang Hidup dan Sosial Ekonomi Masyarakat. Ecotrophic 2: 1-10.

Rusmiharty, Endang. 2015. Menyongsong Masyarakat Ekonomi ASEAN 2015. Materi kuliah umum mahasiswa peserta KKL Prodi Ilmu Administrasi Negara, di Jakarta, 19 Mei 2015.

Sitorus, F. dan I.H. Agusta. 2004. Metodologi Kajian Komunitas. Departemen Ilmu-Ilmu Sosial Ekonomi Fakultas Pertanian Institut Pertanian Bogor dan Program Pasca Sarjana Institut Pertanian Bogor: Bogor.

Sumardjo dan Saharudin, 2006, Tajuk Modul EP-523: Metode-metode Partisipatif dalam Pengembangan Masyarakat, Departemen Komunikasi dan Pengembangan Masyarakat, Fakultas Ekologi Manusia IPB dan Sekolah Pascasarjana IPB: Bogor.

Tjokroamidjojo, Bintoro \& Mustopadidjaja, AR., 1988. Kebijakansanaan dan Administrasi Pembangunan. Jakarta: LP3ES.

Wati, Rahmi. 2016. Pengembangan Industri Ekowisata di Provinsi Bengkulu diakses melalui http://balitbang.bengkuluprov.go.id/pen gembangan-industri-ekowisata-di- 
MIMBAR

JURNAL PENELITIAN SOSIAL DAN POLITIK

September-Desember 2017

provinsi-bengkulu/

\section{Peraturan}

Peraturan Pemerintah Republik Indonesia, Nomor 50 Tahun 2011. Tentang Rencana Induk Pembangunan Kepariwisataan Nasional Tahun 20102025

\section{Website}

http://www.scribd.com/doc/117512025/Strat egi-Pembangunan-PariwisataYogyakarta-Menjadikan-PariwisataYang-Berbasiskan-Kebudayaan\#scribd, tanggal akses 11 Februari 2016, jam 17:30.

http://lifestyle.sindonews.com/read/1073384

/156/promosi-pariwisata-indonesiaungguli-negara-negara-asean$\underline{1451473983}$, akses tanggal 10 Februari 2016, jam 18.00.

http://pariwisata.bengkuluprov.go.id/v3/inde x.php/35-informasi/146-analisa-datakunjungan-wisatawan-ke-provinsibengkulu, akses tanggal 11 Februari 2016, jam 20:45.

http://dokumen.tips/documents/tata-keloladestinasi-pariwisata-berbasis-nilai.html, akses tanggal 10 Februari 2016, jam 16.00 